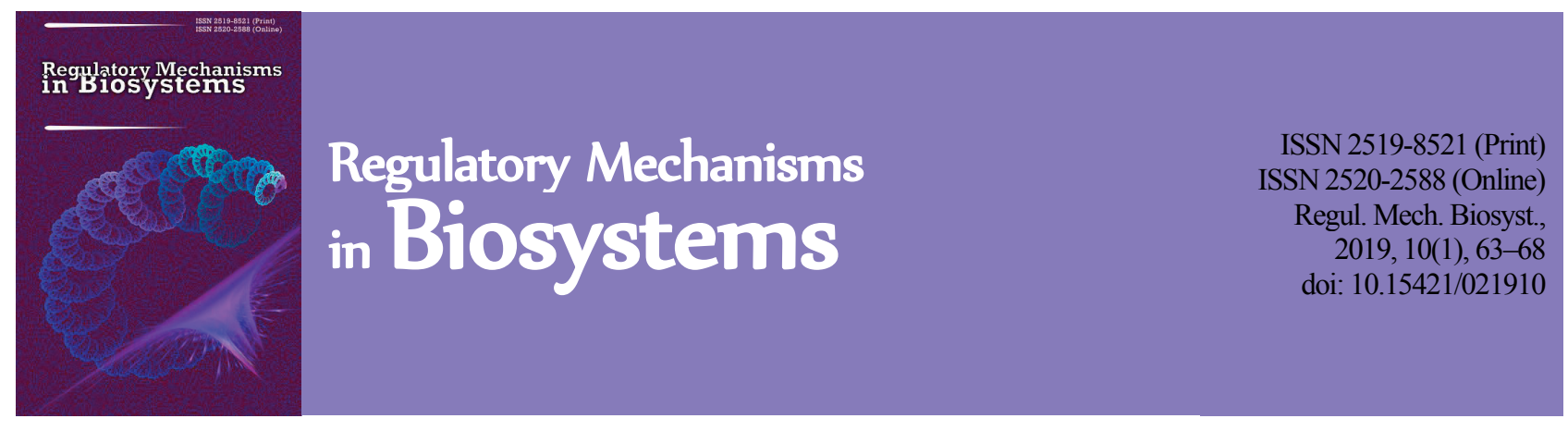

\title{
Differentiation of maize breeding samples by $\beta$-carotene content
}

\author{
T. M. Satarova*, V. V. Semenova*, J. Zhang**, H. Jin**, B. V. Dzubetskii*, V. Y. Cherchel* \\ *The Institute of Grain Crops of National Academy of Agrarian Sciences of Ukraine, Dnipro, Ukraine \\ **Sino-Russian Agricultural Scientific and Technological Cooperation Centre, \\ Heilongjiang Academy of Agricultural Sciences, Harbin, People's Republic of China
}

Article info

Received 24.03.2019

Received in revised form 20.04.2019

Accepted 23.04.2019

The Institute of Grain Crops of National Academy of Agrarian Sciences of Ukraine,

V. Vernadskyst., 14,

Dnipro, 49027, Ukraine.

Tel: +38-056-236-26-18.

E-mail: satarova2008@ukr.net

Sino-Russian Agricultural Scientific and Technological Cooperation Centre

Heilongjiang Academy

of Agricultural Sciences,

Suefulu st., 368 , Harbin, 150086

People's Republic of China.

Tel: +86-451-866-637-26

E-mail: zjm312@aliyun.com
Satarova, T. M., Semenova, V. V., Zhang, J., Jin, H., Dzubetskii, B. V., \& Cherchel, V. Y. (2019). Differentiation of maize breeding samples by $\beta$-carotene content. Regulatory Mechanisms in Biosystems, 10(1), 63-68. doi:10.15421/021910

Plant carotenoids are important micronutrients in the diet of humans and animals, since they act as precursors for the synthesis of vitamin A in animal cells. The most effective precursor to the vitamin A biosynthesis is $\beta$-carotene. Increasing the $\beta$-carotene content in maize grain as an important feed and food crop is an urgent task for plant selection. The purpose of this work was to differentiate maize breeding samples from the Dnipro breeding program by the $\beta$-carotene content in mature grain. Maize grain of 18 inbreds harvested in 2015 and 5 inbreds harvested in 2016 was researched. Determination of $\beta$-carotene content in matured dry grain was carried out after petroleum ether extraction and ultra performance liquid chromatography (UPLC) in the mobile phase of methanol/acetonitrile. The $\beta$-carotene content in the grain of genotypes from the Dnipro breeding program was on average $1.020 \mathrm{mg} / \mathrm{kg}$ for inbreds grown in 2015 , and $0.672 \mathrm{mg} / \mathrm{kg}$ for inbreds grown in 2016 . These values correspond to the $\beta$-carotene content in the grain of the majority of genotypes from world breeding programs selected by methods of classical selection. The inbred DKV3262 with white grain had the smallest content of $\beta$-carotene $(0.076 \mathrm{mg} / \mathrm{kg})$, while the yellow-coloured line DKD9066 had the highest one $(2.146 \mathrm{mg} / \mathrm{kg})$. The variation in the grain $\beta$-carotene content in different years of maize cultivation was noted. Inbreds of flint and semident maize showed the general tendency to increase the $\beta$-carotene content in grain compared with dent ones. The distribution of the studied inbreds on germplasm types showed the significant variation of $\beta$-carotene content in grain and the incidence of relatively high values in all germplasms analyzed. Inbreds containing more than $1.5 \mathrm{mg}$ of $\beta$-carotene per $1 \mathrm{~kg}$ of grain, DK239, DK206A, DK212, DKD9066 and DKE-1, are emphasized as promising for the selection to increase the content of valuable micronutrients.

Keywords: Zea mays; carotenoids; inbred; grain; ultra performance liquid chromatography.

\section{Introduction}

Maize is a source of nutrients for many species of farm animals and humans. Maize grain serves as a supplier of carbohydrates, proteins, lipids, and micronutrients. The latter are substances that in small quantities provide normal metabolism in animal cells. Micronutrients in maize grain primarily involve vitamins. The composition of micronutrients in sweet maize grain, which is consumed at milk ripeness in raw and canned forms, is particularly valuable. Thus, vitamins $\mathrm{B}_{1}, \mathrm{~B}_{5}, \mathrm{~B}_{6}, \mathrm{~B}_{12}$, inositol, choline, biotin, folic and nicotinic acids are contained in the grain of canned sweet maize (Tsikov et al., 2013). Maize grain contains phenol substances that act as antioxidants, in particular, tocochromanols, including $\alpha$-, $\beta$-, $\gamma$-, $\delta$-tocopherols, vitamin E (Zingg \& Azzi, 2004; Menshchikova et al., 2012; Diepenbrock et al., 2017), ferulic acid, anthocyanins in genotypes with coloured grain (Žilić et al., 2012), as well as substances of the carotenoid group.

Carotenoids are unsaturated hydrocarbons that have the empirical formula $\mathrm{C}_{40} \mathrm{H}_{56}$. They are soluble in organic solvents and insoluble in water, are yellow, orange and red pigments (Nesmeyanov \& Nesmeyanov, 1974). In plant cells, biosynthesis and accumulation of carotenoids occur in plastids during the 2-C-methyl-D-erythritol 4-phosphate (MER)cycle (Banerjee \& Sharkey, 2014; Zhai et al., 2016).

The precursor of the synthesis of carotenoids in many plants including maize is geranylgeranyl pyrophosphate (Giuliano, 2014; Zhai et al., 2016). Carotenoids include such important antioxidants and metabolic regulators as lycopene, $\alpha$-, $\beta$-, $\gamma$-, $\delta$-carotenes, zeinoxanthin, lutein, $\beta$-cryptoxanthin, zeaxanthin and others. The most important carotenoids for metabolism in animal cells are precursors of vitamin A synthesis. They include $\alpha$-, $\beta$-carotenes and $\beta$-cryptoxanthin, which are denoted together as provitamin A (Giuliano, 2014).

The animal body is unable to synthesize vitamin A and requires the addition of precursors of its synthesis with food (Zhai et al., 2016). Lack of vitamin A in the human body, which is particularly common in poor countries, leads to serious complications. $\beta$-carotene is the most effective precursor of vitamin A synthesis since one of its molecules provides biosynthesis of two vitamin A molecules at once, in contrast to only one vitamin A molecule for other compounds with A-provitamin activity (Aluru et al., 2008; Guliano, 2014). An adult person should take $1 \mathrm{mg}$ of vitamin A (retinol) or $6 \mathrm{mg}$ of carotenes every day (Hubskyi, 2000); however, the bioavailability of $\beta$-carotene to humans depends on the balance of other carotenoids (Dube et al., 2018).

In a mature maize caryopsis, carotenoids are accumulated in the endosperm (Burt et al., 2010). The main precursor in the maize carotenoid biosynthetic pathway, geranylgeranyl pyrophosphate, under the activity of enzyme phytoene synthase transfers into phytoene. Phytoene in a series of reactions consequentially turns into phytofluene, $\zeta$-carotene, neurosporene and, at last, lycopene. Lycopene is the first coloured compound in the maize carotenoid biosynthetic pathway. If genes controlling the enzymatic reactions of geranylgeranyl pyrophosphate transformation into lycopene have mutations which eliminate fermentative activities, intermediate precursors of lycopene biosynthesis are not synthesized and maize grain appears uncoloured. An especially significant role for the development of yellow pigmentation of maize grain belongs to the gene Yellow 1 (Y1) which encodes enzyme phytoene synthase 1 
(PSY1). Its defect copies cause the absence of grain colouration at once and evoke the formation of ears with white grains (Wong et al., 2004). Carotenes and xanthophylls which are further synthesized from lycopene also provide yellow staining for developing and matured maize caryopses.

It is known that the synthesis and stability of maize carotenoids are under the control of the genotype, environmental factors and the interaction of "genotype $\times$ environment". Characterization of genetic control of carotenoid content is provided in numerous studies of maize genotypes with different alleles of genes responsible for the synthesis of enzymes in each stage of carotenoid biosynthesis (Harjes et al., 2008; Yan et al., 2010; Muthusamy et al., 2015). Among the external factors controlling the content of carotenoids, those affecting mature grain, grain in storage or processing are mostly characterized. Thus, a relationship was established between the content of carotenoids in maize grains and the calendar time of harvest (Alamu et al., 2014), grain moisture at harvesting and the drying method (Burt et al., 2010; Cardoso et al., 2015), the duration, method and conditions of grain storage, in particular, temperature and humidity (Burt et al., 2010; Ortiz et al., 2016; Satarova et al., 2017). The methods of post-harvest processing of maize grain (Ortiz et al., 2018), the storage duration of maize flour after grinding (Kuhnen et al., 2011), the method of culinary processing of maize grain (Alamu et al., 2014) also influenced carotenoid content. At the same time, there is only little indirect evidence of the effect of the conditions of maize plants' cultivation during a growing season on the grain carotenoid content (Satarova et al., 2017). There are proofs that the nature of the influence of the above-mentioned external factors on the accumulation, stability and rate of carotenoid dissociation in maize grain depends on the genotype of the cropping plants and the genotype of endosperm as well as on the interaction of genotypes and environmental factors (Owens et al., 2014; Suwarno et al., 2015; Ortiz et al., 2016; Xu et al., 2017).

Reliable ways to increase the proportion of carotenoids in plants are classical selection and biofortification (Alós et al., 2016; Giuliano, 2017). Significant progress in increasing carotenoid content in maize grain has been achieved through marker-associated selection with molecular genetic markers. They allow one to select initial breeding material with favourable alleles of key genes of phytoene synthase, lycopene $\varepsilon$-cyclase, $\beta$-carotene hydroxylase 1 and others controlling simultaneously economically valuable traits and bioavailability of carotenoids (Muthusamy et al., 2014, 2015; Suwarno et al., 2015; Díaz-Gómez et al., 2017b; Zunjare et al., 2018a, b; Goswami et al., 2019). It is also possible to increase substantially the content of carotenoids in maize due to the genetic engineering methods, in particular, the transfer of foreign genes (Aluru et al., 2008; Federico \& Schmidt, 2016) and RNA interference of genes involved in the $\beta$-carotene biodegradation (Berman et al., 2017). The maximum level of $\beta$-carotene in maize grain, achieved by traditional breeding methods, is $13.6 \mathrm{mg} / \mathrm{kg}$ of grain (Harjes et al., 2008). Genetically engineered improvement through introduction in the maize genome of maize phytoene synthase (psy1) cDNA under the control of the wheat LMW glutenin promoter and the Pantoea ananatis crt gene encoding carotene desaturase under the control of the barley D-hordein promoter led to increase in the $\beta$-carotene content up to $59.3 \mathrm{mg} / \mathrm{kg}$ (Naqvi et al., 2009).

The main method of determining the content of $\beta$-carotene in plant samples is its extraction with a polar solvent followed by ultra performance liquid chromatography (UPLC analysis) (Safawo et al., 2010). Solvents for $\beta$-carotene extraction from plant tissues may be petroleum ether, acetone, hexane, methanol and some others (Craft, 2001; Rodriguez, 2001). At the same time, in some publications, the results of measuring in maize grain and products of its processing the carotenoid content on $\beta$-carotene by spectrophotometry at $450 \mathrm{~nm}$ are given (Scott, 2001; Díaz-Gómez et al., 2017a; Satarova et al., 2017). Since various publications present the results of determining the content of this substance using different solvents and according to modified methods, the correct comparison of maize samples, inbreds and hybrids on $\beta$-carotene content in grain appears contradictory. In addition, discussing the results of breeding work, some researchers point to the content of $\beta$-carotene in grain (Aluru et al., 2008; Harjes et al., 2008; Safawo et al., 2010; Žilić et al., 2012; Alamu et al., 2014; Muthusamy et al., 2014, 2015), while others estimate the content of provitamin $\mathrm{A}$, that is, the mixture of $\alpha$-carotene, $\beta$-carotene and $\beta$-cryptoxanthin (Zunjare et al., 2018a, b), yellow pigments (Radenovic et al., 2015), content of total carotenoids (Aluru et al., 2008; Harjes et al., 2008; Berardo et al., 2009; Safawo et al., 2010; Kuhnen et al., 2011). All this makes it difficult to compare the successes achieved in selection for increasing the $\beta$-carotene content in maize grain.

The levels of $\beta$-carotene, provitamin A, total and individual carotenoid fractions for maize breeding material produced in Ukraine remain almost unexplored. The purpose of our work was to differentiate maize inbreds from the Dnipro breeding program (Ukraine) on the $\beta$-carotene content in mature grain.

\section{Materials and methods}

Material for determination of the $\beta$-carotene content was matured dry grain of maize (Zea mays L.). The grain samples of 18 inbreds harvested in 2015 and 5 inbreds harvested in 2016, having been created within the Dnipro breeding program, were explored. The cultivation of the plants from which the grains were taken for analysis was conducted using the field method (Lebid et al., 2008) in the soil-climatic conditions of the northern subzone of the Ukrainian Steppe in 2015 and 2016. According to the Dnipropetrovsk Centre for Hydrometeorology during the formation and maturation of grain from July to September in both years there was a shortage of precipitation, at $38.8 \%$ from the average annual norm in 2015 and at $10 \%$ in 2016. During this period, the average monthly air temperature was above the average annual rate $14.1 \%$ more in 2015 and $9.4 \%$ more in 2016 . Thus, both research years were characterized by stressful conditions of air temperature and precipitation during the formation and maturation of the grain, but 2015 was more arid and hotter. In both years, grain harvesting was carried out at the end of October. Before analysis grain samples were stored at $+5^{\circ} \mathrm{C}$ in the dark.

The content of $\beta$-carotene in maize grain was determined by ultra performance liquid chromatography (UPLC) according to (Ramachandran et al., 2010; Li et al., 2016) on the Acqualty UPLC ${ }^{\circledR}$ Waters (StepWaveTM, USA) chromatograph, based on the Heilongiiang Academy of Agricultural Sciences (Harbin, China People's Republic) in November 2016. Thus, samples harvested in 2015 were kept for 1 year and 1 month up to the analysis, but samples cropped in 2016 were analyzed within 1 month after harvesting. Extraction of $\beta$-carotene from grain of full ripeness was carried out with petroleum ether. The weighed sample $(5 \mathrm{~g})$ was added with $30 \mathrm{ml}$ of ethyl alcohol and $20 \mathrm{ml}$ of $50 \%$ aqueous $\mathrm{KOH}$ solution and this was refluxed in a boiling water bath for $30 \mathrm{~min}$. Further, the sample flasks were cooled in ice water to room temperature; $50 \mathrm{ml}$ of distilled water was added and transferred to a separating funnel. Then, $100 \mathrm{ml}$ of petroleum ether were added, the samples were vigorously shaken and after setting, the ether fraction was left. This manipulation was repeated three times. The fraction of the petroleum ether was washed with distilled water until $\mathrm{pH}$ value of 7.0 was reached. The fraction of petroleum ether was filtered through the skimmed cotton with anhydrous sodium sulphate. The liquid fraction evaporated at $37^{\circ} \mathrm{C}$. The dry residues containing $\beta$-carotene were dissolved in $5 \mathrm{ml}$ of methanol/acetonitrile $(9: 1 \mathrm{v} / \mathrm{v})$, and then this solution was filtered with $0.22 \mu \mathrm{l}$ of polyvinylidene fluoride with a syringe in a glass vial with a screw cap for automatic sampling in chromatograph. A chromatographic column $\mathrm{C}_{18}$ was used for chromatographic analysis to determine $\beta$-carotene content in the mobile phase of methanol/acetonitrile. UPLC analysis was performed at a sample injection rate of $0.5 \mathrm{ml} / \mathrm{min} .8 \mu \mathrm{l}$ of each sample were injected for UPLS analysis. Detection of $\beta$-carotene was carried out at $448 \mathrm{~nm}$. The content of $\beta$-carotene is given in $\mathrm{mg}$ per $1 \mathrm{~kg}$ of grain $(\mathrm{mg} / \mathrm{kg})$.

Grain for analysis was selected by the mean sample method (Lebid et al., 2008). For all samples, the determination of $\beta$-carotene content was carried out in two analytical repetitions except for five lines with an IKC index, in which the $\beta$-carotene content was determined in one analytical repeat owing to the small amount of grain available for analysis. The obtained data was processed statistically by (Welham et al., 2014). The data in the tables are reported as $\mathrm{x} \pm \mathrm{SE}$ (SE-standard error).

\section{Results}

The analyzed set of inbreds of the Dnipro breeding program (Table 1) contains representatives of the main subspecies, which are widely used in 
the modern production of feed and food maize - flint (14 inbreds), semident (4 inbreds) and dent ( 3 inbreds) subspecies. The involved lines represented the types of germplasm that are common in the global selection process: SSS (B37), Lancaster (Mo17), Lancaster (Oh43), Lancon, Iodent, Euroflint, as well as the germplasm Mix, which was characterized by mixing various germplasm types in the pedigree of an inbred. The DKB3262 line had white grain, but the rest of the samples had yellow grain.

Table 1

Characteristics of maize inbreds used in the study

\begin{tabular}{lcc}
\hline \multicolumn{1}{c}{ Inbred } & Subspecies & Germplasm type \\
\hline DK239MV & flint & SSS (B37) \\
DK633325MV & dent & Mix: Lancaster (Mo17), Mindzenpusta \\
DK272C sterilna & flint & Mix: Euroflint, Lancaster(Oh43), SSS (B37) \\
DKV3262 & dent & SSS (B37) \\
DK206A & flint & Lancon \\
DK212MV & semident & Lancaster (Oh43) \\
DK1855 & flint & Euroflint \\
DKD9066 & semident & Lancaster(Oh43) \\
DK5 & semident & Mix: Co125, Lancaster(Oh43) \\
DK129SV & semident & Mix: Co125, Fundula \\
DK2 & flint & Euroflint \\
DK50-7 & flint & Euroflint \\
DK216SVZM & dent & Iodent \\
IKC2 & flint & Mix (P3945) \\
IKC 3 & flint & Euroflint \\
IKC 12 & flint & Euroflint \\
IKC 21 & flint & Mix (P3945) \\
IKC 30 & flint & Euroflint \\
DK23 & flint & Mix: Lancon, P502 \\
DK276SV & flint & Mix: Dobrudzhanska, P502, Lancaster (Mo17) \\
DK680/168 & dent & Lancaster(Oh43) \\
DKE-1 & flint & Euroflint \\
\hline
\end{tabular}

Figure 1 demonstrates the chromatogram of the $\beta$-carotene content in maize grain on the example of the inbred DK212MV (harvest 2015) after UPLC chromatography.

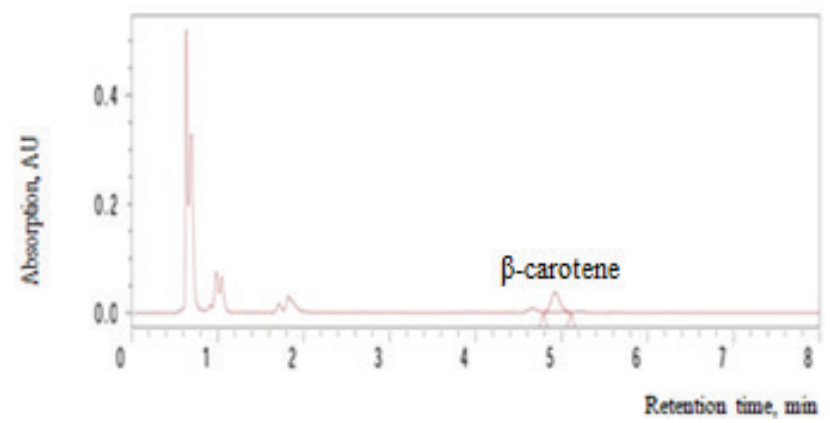

Fig. 1. UPLC chromatogram of $\beta$-carotene extract from the grain of maize inbred DK212MV (in 2015): AU - adsorption units

The $\beta$-carotene content in the grain of 18 inbreds in 2015 (Table 2) ranged from $0.076 \mathrm{mg} / \mathrm{kg}$ in the white grain of DKV3262 to $2.146 \mathrm{mg} / \mathrm{kg}$ in the yellow grain of DKD9066 with an average value of $1.020 \pm 0.280 \mathrm{mg} / \mathrm{kg}$. Among 5 inbreds studied in 2016 (Table 3), the content of $\beta$-carotene in grain varied from $0.181 \mathrm{mg} / \mathrm{kg}$ in DK276SV to $1.659 \mathrm{mg} / \mathrm{kg}$ in DKE-1 with an average value of $0.672 \pm 0.091 \mathrm{mg} / \mathrm{kg}$. Consequently, when comparing the mean values of $\beta$-carotene content, there was no established difference between the sets of breeding samples grown in different years. When comparing the values, except for DK633325MV, which had been investigated both in 2015 and 2016, the reliable difference between years was also not found. However, it should be noted that there was a certain tendency to increase the $\beta$-carotene content in grain in the drier and hotter year 2015 than in 2016 both for the whole experiment as well as for DK633325MV.

Analysis of the variation of $\beta$-carotene content in grain of maize inbreds, depending on their belonging to a certain subspecies or type of germplasm, was conducted according to data of 2015, when more samples were examined (Table 4).

The variation of the studied trait was quite significant within the subspecies (Table 4). Thus, differences in the content of $\beta$-carotene between the inbreds of flint maize amounted up to 4.2 times, semident -6.7 times, but dent maize - 18.2 times. What was more, inbred DKV3262 with white grain and the minimum content of $\beta$-carotene $(0.076 \mathrm{mg} / \mathrm{kg})$ belonged to the dent subspecies. Subspecies significantly differed in average values of $\beta$-carotene content. The highest average value came from the group of semident specimens, which included DKD9066 with the maximum value of the trait. The smallest average content of $\beta$-carotene was in group of dent specimens, although individual inbreds of this group demonstrated considerable accumulation of this substance (DK216SVZM $1.381 \mathrm{mg} / \mathrm{kg}$ ). The distribution of the studied inbreds by the types of germplasm also revealed a significant variation in the content of $\beta$-carotene in the grain and the incidence of its relatively high values in all germplasms analyzed.

Table 2

Content of $\beta$-carotene in grain of maize inbreds, in 2015

\begin{tabular}{|c|c|}
\hline Inbred & $\beta$-carotene, $\mathrm{mg} / \mathrm{kg}$ \\
\hline DK239MV & $1.609 \pm 0.001$ \\
\hline DK633325MV & $0.609 \pm 0.003$ \\
\hline DK272C sterilna & $1.389 \pm 0.191$ \\
\hline DKV3262 & $0.076 \pm 0.008$ \\
\hline DK206A & $1.794 \pm 0.048$ \\
\hline DK212MV & $1.811 \pm 0.090$ \\
\hline DK1855 & $0.783 \pm 0.038$ \\
\hline DKD9066 & $2.146 \pm 0.019$ \\
\hline DK5 & $0.322 \pm 0.059$ \\
\hline DK129SV & $0.828 \pm 0.256$ \\
\hline DK2 & $0.854 \pm 0.208$ \\
\hline DK50-7 & $0.126 \pm 0.050$ \\
\hline DK216SVZM & $1.381 \pm 0.085$ \\
\hline $\mathrm{IKC} 2$ & 1.403 \\
\hline $\mathrm{IKC} 3$ & 1.035 \\
\hline $\mathrm{IKC} 12$ & 0.428 \\
\hline $\mathrm{IKC} 21$ & 1.132 \\
\hline IKC30 & 0.627 \\
\hline
\end{tabular}

Table 3

Content of $\beta$-carotene in grain of maize inbreds, in 2016

\begin{tabular}{lc}
\hline Inbred & $\beta$-carotene, $\mathrm{mg} / \mathrm{kg}$ \\
\hline DK633325MV & $0.588 \pm 0.029$ \\
DK23 & $0.344 \pm 0.003$ \\
DK276SV & $0.181 \pm 0.004$ \\
DK680/168 & $0.590 \pm 0.029$ \\
DKE-1 & $1.659 \pm 0.455$ \\
\hline
\end{tabular}

Table 4

Variation of $\beta$-carotene content in grain of maize inbreds depending on subspecies and type of germplasm, in 2015

\begin{tabular}{lccc}
\hline \multirow{2}{*}{ Group of inbreds } & $\mathrm{n}$ & \multicolumn{2}{c}{$\beta$-carotene, $\mathrm{mg} / \mathrm{kg}$} \\
\cline { 3 - 4 } & \multicolumn{3}{c}{ Subspecies } \\
\hline Flint & 11 & $0.126-1.794$ & average \\
Semident & 4 & $0.322-2.146$ & $1.016 \pm 0.073$ \\
Dent & 3 & $0.076-1.381$ & $0.689 \pm 0.043$ \\
\hline \multicolumn{4}{c}{ Type of germplasm } \\
\hline Iodent & 1 & 1.381 & - \\
Lancaster (Oh43) & 2 & $1.811-2.146$ & - \\
SSS (B37) & 2 & $0.076-1.609$ & - \\
Lancon & 1 & 1.794 & - \\
Euroflint & 6 & $0.126-1.035$ & - \\
Mix & 6 & $0.322-1.403$ & - \\
\hline
\end{tabular}

Note: $\mathrm{n}$ - the number of inbreds studied.

The analysis of the relationship between maize grain colour and the content of carotinoids, in particular, $\beta$-carotene, should be very useful for express estimation of breeding samples for valuable micronutrients, since their chromatographic or spectrophotometric determination is rather complicated and expensive. The grain for share of inbreds analyzed are represented by the increase in $\beta$-carotene content, from the lowest content of $0.076 \mathrm{mg} / \mathrm{kg}$ in DKV3262 to the highest one of $2.146 \mathrm{mg} / \mathrm{kg}$ in DKD9066 (Fig. 2). Inbred DKV3262 has white grain and as expected only a trace amount of $\beta$-carotene (Fig. 2). The other inbreds had yellow grain with varying intensity and shades of colouration. 


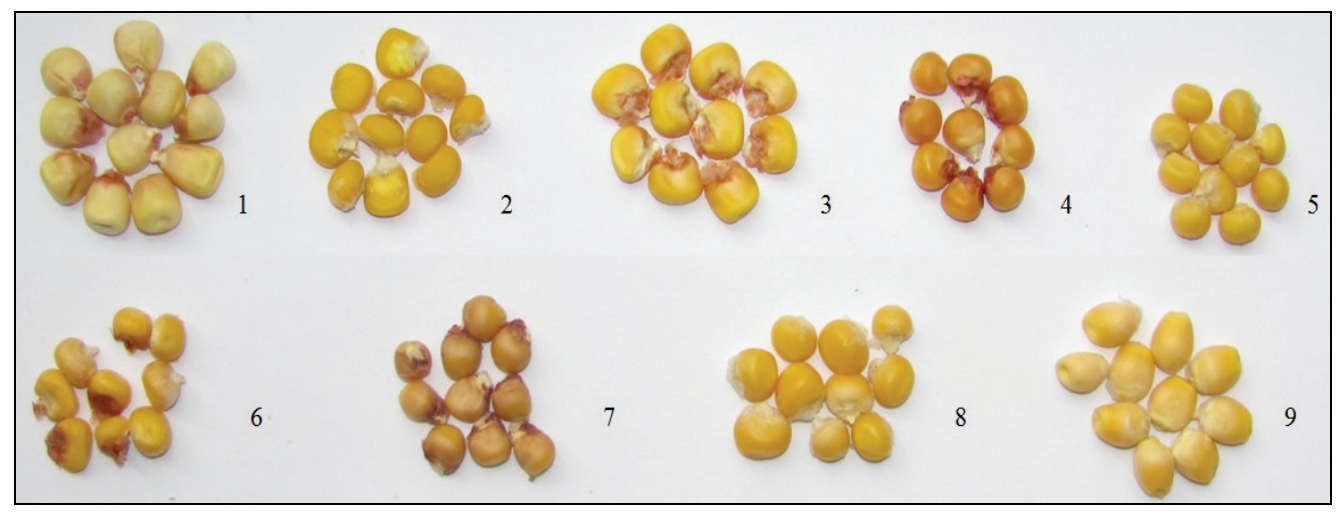

Fig. 2. The colour of grain in several maize inbreds and the content of $\beta$-carotene: 1 - DKV $3262(0.076 \mathrm{mg} / \mathrm{kg})$,

2 - DK276SV (0.181 mg/kg), 3 - DK633325MV (0.609 mg/kg), 4 - DK129SV (0.828 mg/kg), 5 - IKC3 (1.035 mg/kg), 6-DK216SVZM (1.381 mg/kg), 7 - DK239MV (1.609 mg/kg), 8-DK212MV (1.811 mg/kg), 9 - DKD9066 (2.146 mg/kg)

Thus, the most intensive yellow colour was marked for the grain of DK276SV, the least expression of yellow was inherent to DKD9066, while the yellow grain of DK129SV and DK239MV had red-brown and brown shades respectively. At the same time, the magnification of yellow colour intensity in the presented samples was not at all connected with the increase of the $\beta$-carotene content in them. Thus, grain colour of DK276SV and DK212MV was almost the same, but $\beta$-carotene content in the last inbred exceeded it in the first one by 10 times. The gradual increase of $\beta$-carotene content in the submitted samples from DK276SV to DKD9066 was not accompanied by a uniform gradual increase in colour intensity, while the inbred with the highest $\beta$-carotene content DKD9066 had the palest grain among yellow-coloured specimens.

\section{Discussion}

The modern genus Zea is monotypic and contains only one species $Z$. mays $\mathrm{L}$. It is a cultivated species that cannot be found in the wild. But the species $Z$. mays contains a large variety of genotypes created as a result of folk and scientific selection. Modern breeding resources of maize as an intensively grown crop are the result of many cycles of selection among several initial varieties and are now classified by origin into types of germplasm. Types of germplasm (germplasms) are distinct groups within a cultivated species that combine related genotypes (varieties, inbreds, synthetic populations, etc.) (Hallauer et al., 2010). Germplasms Lancaster, Reid, Iodent, Euroflint, Lancon, Mindzenpusta and others are the most common in modern maize breeding due to the high combining ability of their genotypes. Several germplasms are divided into subplasms, for example, Lancaster (Mo17) and Lancaster (Oh43). Separately germplasm Mix stands out, containing resources created via combining several classical germplasms. In research (Harjes et al., 2008) the $\beta$-carotene content in grain of maize standard inbreds of the major germplasms was determined: inbred Mo17 (germplasm Lancaster, subgermplasm Mo17) - $1.1 \mathrm{mg} / \mathrm{kg}$, inbred Oh43 (germplasm Lancaster, subgermplasm Oh43) - $2.254 \mathrm{mg} / \mathrm{kg}$, inbred B37 (germplasm SSS (B37)) $1.15 \mathrm{mg} / \mathrm{kg}$, inbred F2 (germplasm Euroflint) $-0.27 \mathrm{mg} / \mathrm{kg}$, and others. The distribution of inbreds from the Dnipro breeding program of these and other germplasms in the content of $\beta$-carotene in grain showed that they were at the level of the standard inbreds given in (Harjes et al., 2008): Lancaster (Oh43) inbreds - 1.811-2.146 mg/kg, SSS (B37) inbreds $-0.076-1.609 \mathrm{mg} / \mathrm{kg}$, Euroflint inbreds $-0.126-1.035 \mathrm{mg} / \mathrm{kg}$, Iodent inbred $-1.381 \mathrm{mg} / \mathrm{kg}$ ), Lancon inbred $-1.794 \mathrm{mg} / \mathrm{kg}$ and Mix inbreds $-0.322-1.403 \mathrm{mg} / \mathrm{kg}$. Determination of the $\beta$-carotene content in grain of inbreds of the Dnipro breeding program revealed variation within the germplasm types from 1.2 times in Lancaster $(\mathrm{Oh} 43)$ to 8.2 times in Euroflint and as much as 21.2 times in SSS (B37). The latter type included inbred with white grain DKB3262. However, no significant variation between germplasms was noted, the maximum values of $\beta$-carotene content of different plasms varied approximately 2 -fold. One would have been expected to see intensification in the accumulation of $\beta$-carotene in germplasm Mix due to its complex origin. Howe- ver, the findings do not support the hypothesis of increase in the $\beta$-carotene content when combined the genetic materials of various types of germplasm in a genotype of an inbred. Practically, in all plasms there were inbreds with a high level of $\beta$-carotene content as for classical breeding samples $-1 \mathrm{mg} / \mathrm{kg}$ or more. This fact indicates the possibility of selection for high levels of $\beta$-carotene among inbreds and hybrids of all major maize germplasm types.

Maize inbreds DK239MV, DK206A, DK212MV, DKD9066 and DKE-1, which accumulate more than $1.5 \mathrm{mg}$ of $\beta$-carotene per $1 \mathrm{~kg}$ of grain, are recommended as sources of this valuable character. These genotypes are also adapted for field cultivation in Ukraine and promising for heterosis selection. They represent flint and semident subspecies, as well as various types of germplasm - SSS (B37), Lancon, Lancaster (Oh43) and Euroflint. The involvement of such inbreds into hybrids will increase the content of this valuable micronutrient in the grain. However, one should not expect heterosis on $\beta$-carotene content in $F_{1}$ hybrids as it was known that the genetic control of the ability to $\beta$-carotene synthesis was carried out by the genes responsible for each individual stage of the transformation of intermediate metabolites. For $\beta$-carotene, in the absence of mutations in genes of $\beta$-carotene hydroxylase 1 (crtRB1), lycopene$\varepsilon$-cyclase $(l c y \mathrm{E})$ and some others, it is not possible to achieve the heterosis effect on increasing $\beta$-carotene content in $\mathrm{F}_{1}$ hybrids compared to parent forms. Previously we showed (Satarova et al., 2017) that in 2015 the hybrid $F_{1}$ DN Sophia $(\mathrm{DK} 402 \times \mathrm{DK} 633325)$ accumulated in grain $1.63 \pm$ $0.24 \mathrm{mg} \beta$-carotene per $1 \mathrm{~kg}$ of grain, while the hybrid $\mathrm{F}_{1}$ Pochaevsky 190MV (DK744M $\times$ DK2323MV) - only $0.42 \pm 0.01 \mathrm{mg} / \mathrm{kg}$.

Possibly, the heterosis effect on $\beta$-carotene content can be achieved with significant increase via heterosis in the content of carotenoid precursor - geranylgeranyl pyrophosphate. The main precursor to the synthesis of geranylgeranyl pyrophosphate is acetyl coenzyme A. Acetyl coenzyme A is formed as a result of intensive catabolism of a number of compounds, primarily glucose, as well as pyruvate in oxidative decarboxylation. The intensity of these processes as well as glucose synthesis, in $F_{1}$ hybrids can be intensified by heterosis compared to parent lines, which can lead to an increase in the content of geranylgeranyl pyrophosphate in $F_{1}$ hybrids. In this case, the content of $\beta$-carotene in the grain of $F_{1}$ hybrid will be higher than in two parent lines, if they do not contain mutations in $\beta$-carotene hydroxylase 1 and lycopene- $\varepsilon$-cyclase genes. It is very difficult to monitor the content of geranylgeranyl pyrophosphate in developing as well as ripe grain. However, indirectly the level of carotenoids in mature grains of yellow maize may indicate the initial stocks of this substance. In most works on marker-associated maize selection, the total carotenoid content is not often monitored. The total carotenoids in grain were determined for local varieties of white grain maize from Central Malawi (East Africa) at $2.12 \mathrm{mg} / \mathrm{kg}$, but orange grain maize from the same area contained $59.5 \mathrm{mg}$ of total carotenoids per $1 \mathrm{~kg}$ of grain (Hwang et al., 2016). Among genotypes created by methods of classical selection, the maximum level of total carotenoids was reached in North American inbreds at $62.96 \mathrm{mg} / \mathrm{kg}$ (Owens et al., 2014) and $66.0 \mathrm{mg} / \mathrm{kg}$ (Harjes et al., 2008). For the transgenic maize genotype in the study (Naqvi et al., 2009), the maximum 
level of total carotenoids was $163.29 \mathrm{mg} / \mathrm{kg}$. The inspection not only of $\beta$-carotene, but also other precursors of vitamin A synthesis is important for improvement of the food and feed values of maize grain. Thus, the content of provitamin A in the grain of 13 local and exotic genotypes in the publication of Indian researchers, regardless of the allelic state of the lycE-5'UTR marker of lycopene- $\varepsilon$-cyclase gene, was $1.62-23.2 \mathrm{mg} / \mathrm{kg}$ (Zunjare et al., 2018b), while in grain of orange local maize from Central Malawi it amounted to $15 \mathrm{mg} / \mathrm{kg}$ (Hwang et al., 2016). The content of provitamin A assumed as $\beta$-carotene, half of $\alpha$-carotene and half of $\beta$ cryptoxanthin contents, in the grain of the classic USA inbreds (Indiana) was $0.81-5.55 \mathrm{mg} / \mathrm{kg}$ (Owens et al., 2014). In the common breeding samples in the Indian breeding program, the content of provitamin A measured as $\beta$-carotene and half of $\beta$-cryptoxanthin contents, was 1.65 $2.04 \mathrm{mg} / \mathrm{kg}$ for inbreds and $2.14-2.48 \mathrm{mg} / \mathrm{kg}$ for hybrids. After recurrent marker-assisted selection on the markers of the $c r t \mathrm{RB} 1$ and $l c y \mathrm{E}$ genes, elite inbreds provided the content of provitamin A at 7.38-13.59 mg/kg and hybrids at $9.25-12.88 \mathrm{mg} / \mathrm{kg}$ (Zunjare et al., 2018a). The genotypes from the CIMMYT-Harvest Plus (India) program with the favourable marker allele of $l c y \mathrm{E} 5$ 'UTR achieved provitamin A content up to $22.28 \mathrm{mg} / \mathrm{kg}$ (Zunjare et al., 2018b). The maximum content of provitamin $A$ at $71.86 \mathrm{mg} / \mathrm{kg}$ was detected in transgenic maize by increasing the content of $\beta$-carotene up to $59.32 \mathrm{mg} / \mathrm{kg}, \alpha$-carotene up to $7.26 \mathrm{mg} / \mathrm{kg}$, and $\beta$-cryptoxanthin up to $5.28 \mathrm{mg} / \mathrm{kg}$ (Naqvi et al., 2009).

There is a discussion in the literature concerning the correlation of carotenoid content, on the one hand, and the presence and intensity of the colour of maize grain, on the other. The existence of such a connection could be the basis for an express method of estimation and screening of samples in selection for high levels of carotenoids, in particular, $\beta$-carotene. In our study, there was no such relationship between the intensity of grain yellow colour and the content of $\beta$-carotene in it. There is no unambiguous evidence of such correlation as well as in the publications of those authors who studied this problem for maize specimens with yellow grain (Harjes et al., 2008; Safawo et al., 2010). This is understandable since carotenoids including $\beta$-carotene are synthesized in maize grain during its maturation, in particular, at the beginning of the formation of preconditions for caryopsis entering into a period of dormancy. Certain fractions of carotenoids at that time pass into others, all carotenes and xanthophylls stain grains in different shades of yellow, under the transition of some fractions into others general colouration remains.

There is a totally different relationship between the lack of colour (white grain), the presence of colour (yellow grain) and the $\beta$-carotene content. In our study, the inbred with white grain DKV3262 had only a trace amount of $\beta$-carotene. This can be explained by the existence of the mutation of the phytoene synthase gene Yellow 1 in homozygous state (genotype $y l y l$ ). In the mutant state of the phytoene synthase gene, the precursor of the synthesis of the first coloured product in the chain of carotenoid biosynthesis - lycopene is not formed due to a violation of the synthesis of phytoene from geranylgeranyl pyrophosphate, and the grain remains white. The gene Yellow 1 and the enzyme phytoene synthase play a key role in condensing two molecules of geranylgeranyl pyrophosphate into one phytoene molecule. Gene Yellow 1 is located on chromosome 6, in bin 6.01. Two mutations in this gene are known: indel of 378 b.p. upstream of the transcription start site and a polymorphic SNP site in the fifth exon, which leads to the replacement of threonine with asparagine (Fu et al., 2013). It can be assumed that the presence of the trace amount of $\beta$-carotene in externally white grain of DKV3262 is associated with the emergence of mosaicism on the somatic mutations of the Yellow 1 gene in several endosperm cells.

The results received from the given investigation and the publications of other researchers show the directions of the work when selecting for the optimization of the content of the carotenoid group micronutrients, in particular, $\beta$-carotene. Thus, selection for the increase of these specific substances contents should be carried out taking into account the content of geranylgeranyl pyrophosphate in forming and mature grain, evaluated by total carotenoids content. It is also necessary to monitor the content of $\beta$-carotene in grain not only at the time of harvesting, but also during the utilization of maize grain in cattle and poultry farming and the food industry, as they can vary significantly. In particular, such control is important for compound feedstuff, ground grain, maize flour, etc. at the time of their production as well as in storage, processing, under heat treatment etc. One should note the negative effects of light, steam, pressure on the stability of $\beta$-carotene in food and feed. For increasing $\beta$-carotene content in immature grain of sweet corn when the transformation of $\beta$-carotene into $\beta$-cryptoxanthin is not completed, monitoring of geranylgeranyl pyrophosphate content by the amount of total carotenoids is important. It should be done during grain formation and at the milk (technical) ripeness, as well as the control of $\beta$-carotene content at picking up of ears in milk ripeness. In order to provide the necessary micronutrients of the carotenoid group, it is also appropriate to control the content of provitamin A, in particular, $\beta$-carotene in sweet corn grain after cooking in various manners (boiling, baking, ears without husks, ears in husks, shelled grain), in canned sweet corn at the time of production and under storage.

\section{Conclusion}

As a result of the determination of the $\beta$-carotene content in maize grain by ultra performance liquid chromatography, it was found that the inbreds of the Dnipro breeding program contained $\beta$-carotene in grain at an average of $1.020 \pm 0.280 \mathrm{mg} / \mathrm{kg}$ (year 2015) and $0.672 \pm 0.091 \mathrm{mg} / \mathrm{kg}$ (year 2016), which corresponded to the content of this micronutrient in the grain of inbreds in world breeding programs. The amount of $\beta$-carotene in maize inbreds changed in different years of plant cultivation and varied by subspecies, with the grain of flint and semident maize accumulating on average more $\beta$-carotene than the dent one. The distribution of the studied inbreds by types of germplasm also revealed a significant variation of $\beta$-carotene content in grain and the incidence of its relatively high values in all main germplasm types. The relationship between intensity of grain yellow colour and $\beta$-carotene content was not found.

Among the inbreds analyzed, the smallest content of $\beta$-carotene was discovered in white-grain DKB3262 $(0.076 \mathrm{mg} / \mathrm{kg})$, but the highest one - in yellow-coloured DKD9066 (2.146 mg $/ \mathrm{kg})$. Inbreds DK239MV, DK206A, DK212MV, DKD9066 and DKE-1, which accumulated more than $1.5 \mathrm{mg}$ of $\beta$-carotene per $1 \mathrm{~kg}$ of grain, were recommended as sources of this valuable trait.

The authors express their gratitude to the candidate of agricultural sciences E. I. Belikov for grain samples of inbreds IKC2, IKC 3, IKC12, IKC21 and IKC30 provided for the research, and also Y. O. Goncharov for technical support in extraction of $\beta$-carotene.

The work was carried out within the project "Joint Laboratory for Scientific and Technical Cooperation in the Field of Agriculture between China, UIS and Central and Eastern Europe Countries " (2016AE6AE001) under the Cooperation Agreement between the Heilongjiang Academy of Agricultural Sciences (People's Republic of China, Harbin) and the Institute of Grain Crops of NAAS of Ukraine (Ukraine, Dnipro).

\section{References}

Alamu, E. O., Menkir, A., Mziya-Dixon, B., \& Olaofe, O. (2014). Effects of husk and havest time on carotenoid content and acceptability of roasted fresh cobs of orange maize hybrids. Food Science and Nutrition, 2(6), 811-820.

Alós, E., Rodrigo, M. J., \& Zacarias, L. (2016). Manipulation of carotenoid content in plants to improve human health. Subcellular Biochemistry, 79, 311-343.

Aluru, M., Xu, Y., Guo, R., Wang, Z., Li, S., White, W., Wang, K., \& Rodermel, S. (2008). Generation of transgenic maize with enhanced provitamin A content. Journal of Experimental Botany, 59(13), 3551-3562.

Banerjee, A., \& Sharkey, T. D. (2014). Methylerythritol 4-phosphate (MEP) pathway metabolic regulation. Natural Product Reports, 31(8), 1043-1055.

Berardo, N., Mazzinelli, Y., Valoti, P., Lagana, P., \& Redaelli, R. (2009). Characterization of maize germplasm for the chemical composition of the grain. Journal of Agricultural and Food Chemistry, 57(6), 2378-2384.

Berman, J., Zorrilla-López, U., Sandmann, G., Capell, T., Christou, P., \& Zhu, C. (2017). The silencing of carotenoid $\beta$-hydroxylases by RNA interference in different maize genetic backgrounds increases the $\beta$-carotene content of the endosperm. International Journal of Molecular Sciences, 18(12), 2515-2528.

Burt, A. J., Grainger, C. M., Young, J. C., Shelp, B. J., \& Lee, E. A. (2010). Impact of postharvest handling on carotenoid concentration and composition in highcarotenoid maize (Zea mays L.) kernels. Journal of Agricultural and Food Chemistry, 58, 8286-8292.

Cardoso, W. S., Borêm, A., Karam, D., Rios, S. de A., \& Paes, M. C. D. (2015) Influence of the moisture at harvest and drying process of the grains on the 
level of carotenoids in maize (Zea mays). Food Science and Technology, $35(3), 481-486$.

Craft, N. E. (2001). Chromatographic techniques for carotenoid separation. Current Protocols in Food Analytical Chemistry, 1, F2.3.1-F2.3.15.

Díaz-Gómez, J., Moreno, J. A., Angulo, E., Sandmann, G., Zhu, C., Capell, T., \& Nagareda, C. (2017a). Provitamin A carotenoids from an engineered highcarotenoid maize are bioavaible and zeaxanthin does not compromise $\beta$-carotene absorption in poultry. Transgenic Research, 26(5), 591-601.

Díaz-Gómez, J., Ramos, A. J., Zhu, C., Martin-Belloso, O., \& Soliva-Fortuny, R. (2017b). Influence of cooking conditions on carotenoid content and stability in porridges prepared from high-carotenoid maize. Plant Foods for Human Nutrition, 72(2), 113-119.

Diepenbrock, C. H., Kandianis, C. B., Lipka, A. E., Magallanes-Lundback, M., Vaillancourt, B., Gongora-Castillo, E., Wallace, J. G., Cepela, J., Mesberg, A., Bradbury, P. J., Ilut, D. C., Mateos-Hernandez, M., Hamilton, J., Owens, B. F., Tiede, T., Buckler, E. S., Rocheford, T., Buell, C. R., Gore, M. A., \& DellaPenna, D. (2017). Novel loci underlie natural variation in vitamin E levels in maize grain. Plant Cell, 29(10), 2374-2392.

Dube, N., Mashurabad, P. C., Hossain, F., Pullakhandam, R., Thinganing, L., \& Bharatraj, D. K. (2018). $\beta$-Carotene bioaccessibility from biofortified maize (Zea mays) is related to its density and is negatively influenced by lutein and zeaxanthin. Food and Function, 9(1), 379-388.

Federico, M. L., \& Schmidt, M. A. (2016). Modern breeding and biotechnological approaches to enhance carotenoid accumulation in seeds. Subcellular Biochemistry, 79, 345-358.

Fu, Z., Chai, Y., Zhou, Y., Yang, X., Warburton, M. L., Xu, S., Cai, Y., Zhang, D., Li, J., \& Yan, J. (2013). Natural variation in the sequence of PSY1 and frequency of favourable polymorphisms among tropical and temperate maize germplasm. Theoretical and Applied Genetics, 126, 923-935.

Giuliano, G. (2014). Plant carotenoids: Genomics meets multi-gene engineering. Current Opinion in Plant Biology, 19, 111-117.

Giuliano, G. (2017). Provitamin A biofortification of crop plants: A gold rush with many miners. Current Opinion in Biotechnology, 44, 169-180.

Goswami, R., Zunjare, R. U., Khan, S., Baveja, A., Muthusamy, V., \& Hossain, F. (2019). Marker-assisted introgression of rare allele of $\beta$-carotene hydroxylase (crtRB1) gene into elite quality protein maize inbred for combining high lysine, tryptophan and provitamin A in maize. Plant Breeding, in pruint.

Harjes, C. E., Rocheford, T. R., Bai, L., Brutnell, T. R., Kandianis, C. B., Sowinski, S. G., Stapleton, A. E., Vallabhaneni, R., Williams, M., Wurtzel, E. T., Yan, J., \& Buckler, E. S. (2008). Natural genetic variation in lycopene epsilon cyclase tapped to maize biofortification. Science, 319(5861), 330-333.

Hubskyi, Y. I. (2000). Biolohichna khimiia [Biological chemistry]. Ukrmedknyha, Kyiv - Ternopil (in Ukrainian)

Hwang, T., Ndolo, V. U., Katundu, M., Nyirenda, B., Bezner-Kerr, R., Arntfield, S., \& Beta, T. (2016). Provitamin A potential of landrace orange maize variety (Zea mays L.) grown in different geographical locations of Central Malawi. Food Chemistry, 196, 1315-1324.

Kuhnen, S., Lemos, P. M., Campestrini, L. H., Ogliari, J. B., Dias, P. F., \& Maraschin, M. (2011). Carotenoid and anthocyanin contents of grains of Brazilian maize landraces. Journal of the Science of Food and Agriculture, 91(9), 1548-1553.

Lebid, Y. M., Tsykov, V. S., Pashchenko, Y. M., Shevchenko, M. S., Kyrpa, M. Y., \& Pashchenko, N. O. (2008). Metodyka provedennia polovykh doslidiv z kukurudzoiu [Method of conducting field experiments with corn]. Institute of Grain Crops of NAAS of Ukraine, Dnipro (in Ukrainian).

Li, W., Zhai, S., Jin, H., Wen, W., Liu, J., Xia, X., \& He, Z. (2016). Genetic variation of carotenoids in Chinese bread wheat cultivars and the effect of the 1BL.1RS translocation. Frontiers of Agricultural Science and Engineering, 3(2), 124-130.

Menshchikova, E. B., Lankin, V. Z., \& Kandalintseva, N. V. ( 2012). Fenolnyye antioksidanty $\mathrm{v}$ biologii i meditsine [Phenolic antioxidants in biology and medicine]. Lap Lambert, Saarbrücken (in Russian).

Muthusamy, V., Hossain, F., Thirunavukkarasu, N., Choudhary, M., Supradip, C., Bhat, J. S., Prasanna, B. M., \& Gupta, H. S. (2014). Development of $\beta$-carotene rich maize hybrids through marker-assisted introgression of $\beta$-carotene hydroxylase allele. PLoS One, 9(12), e113583.

Muthusamy, V., Hossain, F., Thirunavukkarasu, N., Saha, S., \& Gupta, H. S. (2015). Allelic variations for lycopene- $\varepsilon$-cyclase and $\beta$-carotene hydroxylase genes in maize inbreds and their utilization in $\beta$-carotene enrichment programme. Cogent Food and Agriculture, 1, 1033141.

Muzhingi, T., Palacios-Rojas, N., Miranda, A., Cabrera, M. L., Yeum, K. J., \& Tang, G. (2017). Genetic variation of carotenoids, vitamin $\mathrm{E}$ and phenolic compounds in provitamin A biofortified maize. Journal of the Science of Food and Agriculture, 97(3), 793-801.

Naqvi, S., Zhu, C., Farre, G., Ramessar, K., Bassie, L., Breitenbach, J., Conesa, D. P., Ros, G., Sandmann, G., Capell, T., \& Christou, P. (2009). Transgenic multivitamin corn through biofortification of endosperm with three vitamins representing three distinct metabolic pathways. Proceedings of the National Academy of Sciences of the United States of America, 106(19), 7762-7767.

Nesmeyanov, A. N., \& Nesmeyanov, N. A. (1974). Nachala organicheskoy khimii. Knyha 1 [The beginnings of organic chemistry. Book 1]. Chemistry, Moscow (in Russian).

Ortiz, D., Ponrajan, A., Bonnet, J. P., Rocheford, T., \& Ferruzzi, M. G. (2018). Carotenoid stability during dry-milling, storage and extrusion processing of biofortified maize genotypes. Journal of Agricultural and Food Chemistry, 66(18), 4683-4691.

Ortiz, D., Rocheford, T., \& Ferruzzi, M. G. (2016). Influence of temperature and humidity on the stability of carotenoids in biofortified maize (Zea mays L.) genotypes during controlled postharvest storage. Journal of Agricultural and Food Chemistry, 64(13), 2727-2736.

Owens, B. F., Lipka, A. E., Magallanes-Lundback, M., Tiede, T., Diepenbrock, C. H., Kandianis, C. B., Kim, E., Cepela, J., Mateos-Hemandez, M., Buell, C. R., Buckler, E. S., DellaPenna, D., Gore, M. A., \& Rocheford, T. (2014). A foundation for provitamin A biofortification of maize: Genome-wide association and genomic prediction models of carotenoid levels. Genetics, 198(4), 1699-1716.

Radenovic, C., Delich, N., Sechansky, M., \& Jovanovic, Z., Stankovic, G., \& Popovich, A. (2015). Inbrednye linii i gibridy kukuruzy (Zea mays L.) serbskoj selekcii s vysokoj effektivnost'ju fotosinteza, obogashhennym pigmentnym sostavom i povyshennoj pitatel'noj cennost'ju [Maize (Zea mays L.) inbred lines and hybrids of Serbian selection with high efficiency of photosynthesis, rich in pigment content and increased nutritive value]. Agricultural Biology, 50(5), 600-610 (in Russian).

Ramachandran, A., Pozniak, C. J., Clarke, J. M., \& Singh, A. K. (2010). Carotenoid accumulation during grain development in durum wheat. Journal of Cereal Science, 52(1), 30-38.

Rodriguez, G. A. (2001). Extraction, isolation, and purification of carotenoids. Current Protocols in Food Analytical Chemistry, 1, F2.1.1-F2.1.8.

Safawo, T. J., Senthil, N., Raveendran, M., Vellaikumar, S., Ganesan, K. N., Nallathambi, G., Saranya, S., Shobhana, V. G., Abirami, B., \& Gowri, V. (2010). Exploitation of natural variability in maize for $\beta$-carotene content using HPLC and gene specific markers. Electronic Journal of Plant Breeding, 1(4), 548-555.

Satarova, T. M., Borisova, V. V., Goncharov, Y. O., Zhouymei, Z., \& Hui, J. (2017). Variiuvannia vmistu $\beta$-karotynu v zerni kukurudzy v protsesi yoho zberihannia [Variation of the content of $\beta$-carotene in maize grains in the process of its storage]. Grain Crops, 1(1), 40-44 (in Ukrainian).

Scott, K. J. (2001). Detection and measurement of carotenoids by UV/VIS spectrophotometry. Current Protocols in Food Analytical Chemistry, 1, F2.2.1-F2.2.10.

Suwarno, W. B., Pixley, K. V., Palacios-Rojas, N., Kaeppler, S. M., \& Babu, R. (2015). Genome-wide association analysis reveals new tagets for carotenoid biofortification in maize. Theoretical and Applied Genetics, 128(5), 851-864.

Tsikov, V. S., Konoplya, N. I., \& Masliyev, V. (2013). Kukuruza na pishchevyye i lekarstvennyye tseli: Proizvodstvo i ispolzovaniye [Maize for food and medicinal purposes: production and using]. Shiko, Lugansk (in Russian).

Welham, S. J., Gezan, S. A., Clark, S. J., \& Mead, A. (2014). Statistical methods in biology: Design and analysis of experiments and regression. CRC Press, Boca Raton.

Wong, J. C., Lambert, R. J., Wurtzel, E. T., \& Rocheford, T. R. (2004). QTL and candidate genes phytoene synthase and zeta-carotene desaturase associated with the accumulation of carotenoids in maize. Theoretical and Applied Genetics, 108(2), 349-359.

Xu, X., Wang, M., Li, L., Che, R., Li, P., Pei, L., \& Li, H. (2017). Genome-wide trait-trait dynamics correlation study dissects the gene regulation pattern in maize kernels. BMC Plant Biology, 17(1), 163.

Yan, J., Kandianis, C. B., Harjes, C. E., Bai, L., Kim, E. H., Yang, X., Skinner, D. J., Fu, Z., Mitchell, S., Li, Q., Fernandez, M. G. S., Zaharieva, M., Babu, R., Fu, Y., Palacios, N., Li, J., DellaPenna, D., Brutnell, T., Buckler, E. S., Warburton, M. L., \& Rocheford, T. (2010). Rare genetic variation at Zea mays crtRB1 increases $\beta$-carotene in maize grain. Nature Genetics, 42(4), 322-327.

Zhai, S. N., Xia, X. C., \& He, Z. H. (2016). Carotenoids in staple cereals: metabolism, regulation and genetic manipulation. Frontiers in Plant Science, 7, 1197.

Žilić, S., Serpen, A., Akillioğlu, Y., Gőkmen, V., \& Vančetović, J. (2012). Phenolic compounds, carotenoids, anthocyanins and antioxidant capacity of colored maize (Zea mays L.) kernels. Journal of Agricultural and Food Chemistry, 60(5), 1224-1231.

Zingg, J. M., \& Azzi, A. (2004). Non-antioxidant activities of vitamin E. Current Medicinal Chemistry, 11(9), 1113-1133.

Zunjare, R. U., Chhabra, R., Hossain, F., Baveja, A., Muthusamy, V., \& Gupta, H. S. (2018a). Molecular characterization of 5'UTR of the lycopene epsilon cyclase (IcyE) gene among exotic and indigenous inbreds for its utilization in maize biofortification. 3 Biotech, 8(1), 75.

Zunjare, R. U., Hossain, F., Muthusamy, V., Baveja, A., Chauhan, H. S., Bhat, J. S., Thirunavukkarasu, N., Saha, S., \& Gupta, H. S. (2018b). Development of biofortified maize hybrids through marker-assisted stacking of $\beta$-carotene hydroxylase, lycopene-E-cyclase and opaque 2 genes. Frontiers in Plant Science, 9, 178. 